\title{
ULTRASTRUCTURAL CHANGES IN CHLOROPLASTS OF MESOPHYLL CELLS OF CHLOROTIC AND PREMATURELY YELLOWED LEAVES OF BETULA PENDULA ROTHR.
}

\author{
KRYSTYNA PRZYBYŁ ${ }^{1}$, KRYSTYNA IDZIKOWSKA $^{2}$ \\ ${ }^{1}$ Department of Tree Diseases, Institute of Dendrology, \\ Polish Academy of Sciences \\ ul. Parkowa 5, 62-035 Kórnik, Poland \\ e-mail: kmtprz@man.poznan.pl \\ ${ }^{2}$ Laboratory of Electron Microscopy, Faculty of Biology, \\ Adam Mickiewicz University \\ ul. Grunwaldzka 6, 60-780 Poznań, Poland
}

(Received: April 9, 2003. Accepted: October 13, 2003)

\begin{abstract}
The ultrastructure of chloroplasts was studied in mesophyll cells of the leaves of silver birch (Betula pendula) showing interveinal chlorosis or premature yellowing, in comparison with leaves without symptoms or exhibiting symptoms of natural senescence. The leaves were collected between May 26 to June 7 and additionally in the September 10-12 from the upper part of the crown, from increments of the past four years. No major difference in ultrastructure of chloroplasts was found between spongy and palisade mesophyll cells. The following senescencerelated changes were observed in chloroplasts of prematurely yellowed leaves and showing inteveinal chlorosis: reduced chloroplast size, degeneration of the membrane systems of thylakoids and increased electron density of plastoglobuli. The most electron dark globules (lipid droplets) were found together with starch grains in cells of spongy mesophyll of leaves showing interveinal chlorosis. Abnormal, spherical and rounded chloroplasts with electron-dark inside of thylakoids or the electron-dark stroma between thylakoids were found only in yellowed and chlorotic leaves in spring.
\end{abstract}

KEY WORDS: Betula pendula, leaves, interveinal chlorosis, premature yellowing, chloroplasts, TEM.

\section{INTRODUCTION}

For ten years, decline of birch stands (Betula pendula) has been recorded in Poland, but its intensity varied from one birch stand to the next. The most noticeable macroscopic symptoms occurring in above-ground organs are as follows: crown thinning due to dieback of fine twigs and branches in the tree-top, wounds and slime flux on the trunk, brown bark and sapwood inside branches and trunk, showing sometimes a water-saturated appearance (Przybył et al. 1998; Przybył and Żłobińska-Podejma 2000; Przybył 2001). Leaves of the declining trees usually turn yellow prematurely. Irrespective of this symptoms, chlorosis between veins of leaves is observed in majority of trees. It is suspected that the symptoms in birch leaves could be related to the prolonged periods of drought recorded in Poland in the past few years. Moreover, it seems plausible that the $\mathrm{K}, \mathrm{Mg}$, and $\mathrm{N}$ deficiency is involved in accelerated yellowing (Przybył and Mańka 2000).

The ultrastructure of birch leaves has been studied during the autumnal senescence and in relation to injures in- duced by ozone together with drought by Dodge (1970), Günthardt et al. (1993), Pääkkönen et al. (1995), Pääkkönen et al. (1997) and Pääkkönen et al. (1998). However to our knowledge there is a little information available from the literature on ultrastructural changes in chloroplasts with regard to macroscopic disease symptoms occurring on the leaves of declining trees.

The purpose of this research was to compare chloroplast ultrastructure in mesophyll cells of birch leaves showing interveinal chlorosis or yellowing of whole leaf blades in spring and of leaves without symptoms or exhibiting symptoms of natural senescence.

\section{MATERIALS AND METHODS}

\section{Plant material and sampling methods}

The study was conducted on silver birch trees aged 40-46 . The trees grew on previously established experimental plots situated in following forest districts: Bierzwnik, Lipinki Łużyckie and Jarocin. Leaves showing some visual 
TABLE 1. Collection sites and periods of Betula pendula leaves showing disease changes.

\begin{tabular}{llc}
\hline 1. Forest Division & Disease changes on leaves & Collection \\
2. Department & & \\
3. Type of forest site and age of trees & chlorosis between veins of blade leaf & late May \\
\hline $\begin{array}{l}\text { 1. Bierzwnik } \\
\text { 2. Kosobudka (protective zone) }\end{array}$ & & early June \\
3. Ca. 40 & yellowing of blade leaf & \\
\hline $\begin{array}{l}\text { 1. Lipinki Łużyckie } \\
\text { 2. Lipinki } 781\end{array}$ & & spring - without disease symptoms (control 1) \\
3. Wet coniferous mixed forest, 46 & autumn - yellowing of blade leaf (control 2) & early June \\
\hline $\begin{array}{l}\text { 1. Jarocin } \\
\text { 2. Gorzyce, } 89 j\end{array}$ & \\
3. Wet coniferous mixed forest, 40 & & mid September \\
\hline
\end{tabular}

symptoms (Table 1, Fig. 1) and without macroscopic changes were harvested in the morning between May 26 to June 7 and additionally in the September 10-12 from the upper part of the crown of uprooted or removed trees, from increments of the past four years. The material was transported directly to the laboratory in portable iceboxes (at $5-10^{\circ} \mathrm{C}$ ).

\section{Sample preparation for transmission electron microscopy (TEM)}

After cool transportation to the laboratory within one day, small sections (ca $2 \mathrm{~mm} \times 2 \mathrm{~mm}$ ) were cut from middle part of the blade (near the main vein) of five leaves for each stand. The samples were immediately fixed in chilled $4 \%$ glutaraldehyde in $0.1 \mathrm{M}$ cacodylate buffer at $\mathrm{pH} 7.2$ for $20 \mathrm{~h}$ at $4^{\circ} \mathrm{C}$ and then rinsed in the same buffer. Postfixation was carried out in $1 \%$ osmium tetroxide $\left(\mathrm{OsO}_{4}\right)$ in the cacodylate buffer for $2 \mathrm{~h}$ at $4{ }^{\circ} \mathrm{C}$ and then treated with $2 \%$ uranyl acetate for $2 \mathrm{~h}$. Subsequently the material was dehydrated as follows: a) in a graded series of ethanol (30-90\%), b) in ethanol-aceton mixtures $(90 \%$ ethanol and $90 \%$ acetone (1:1) and $90 \%$ ethanol and $96 \%$ acetone (1:1) c) in absolute acetone and d) in $99 \%$ propylene oxide. The samples were embedded in Epon 812. Ultrathin sections were obtained with using ultramicrotome Leica-Ultraent S. Ultrathin (ca. 70-90 nm thick) sections were poststained with uranyl acetate and lead citrate (Reynolds 1963) and viewed using Je- ol type 1200 EX transmission electron microscope at an accelerating voltage of $80 \mathrm{keV}$.

The length of chloroplasts were measured from the photographs (Pääkkönen et al. 1995).

\section{RESULTS}

\section{Leaves without symptoms in spring (control 1)}

No apparent cytological differences were noted between the palisade and spongy mesophylls. Two types of the cells were observed in both kinds of mesophylls with regard to the degree of vacualisation. One type had a large central vacuole with the other organelles situated in the periphery of cells. Mesophyll cells of the other type contained several vacuoles, smaller than in the first type, scattered in the cytoplasm. The cytoplasm of all observed cells was dense and contained minute granules. Besides, other organelles were evident inside both types of cells: nucleus, mitochondria, chloroplasts and endoplasmic reticulum.

Lens-shaped and elongated chloroplasts in cells of both palisade and spongy mesophylls were 4.0-5.5(-6) $\mu \mathrm{m}$ long. They exhibited a well-developed internal membrane system, which was electron-light (more transparent than stroma). Some chloroplasts contained usually electron-light globules of various size and number (Fig. 2). Small and single starch grains were sporadically observed.
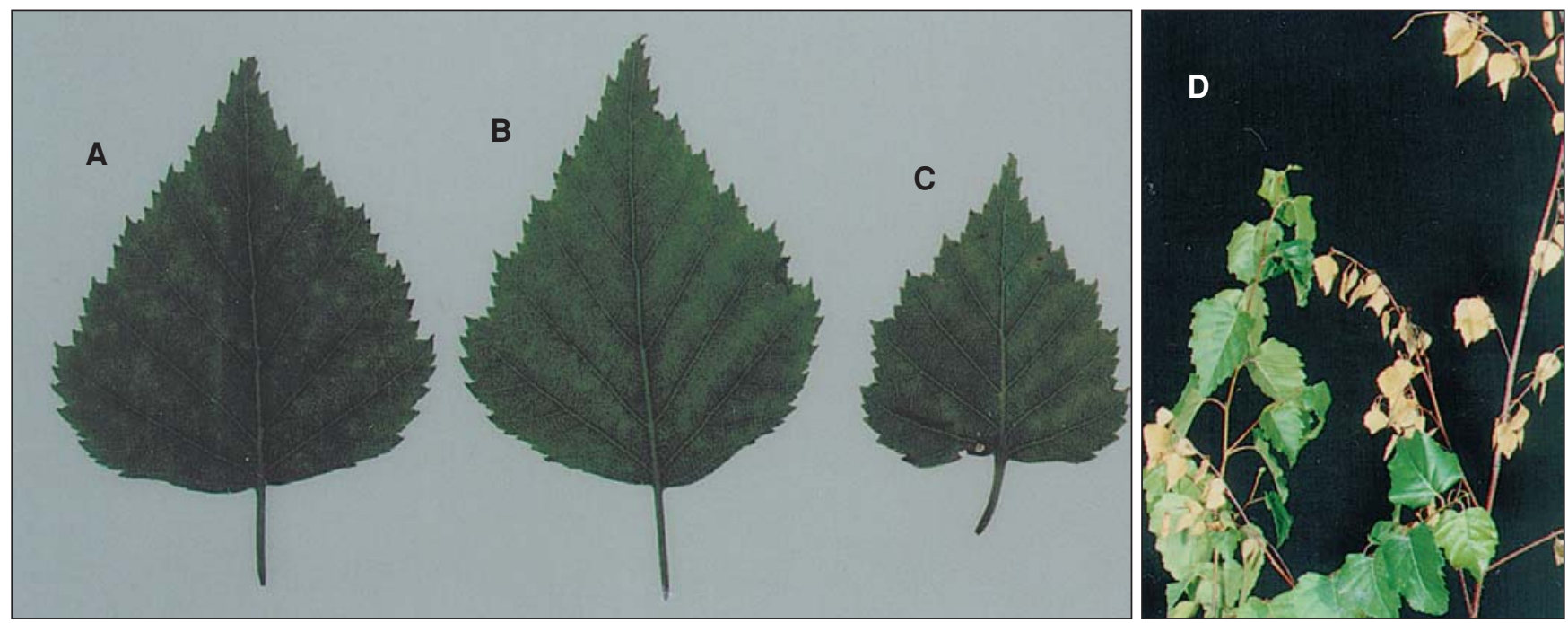

Fig. 1. Disease symptoms of leaves of B. pendula: chlorosis between veins - A, B, C; leaves without symptoms and yellowed in late spring - D. 

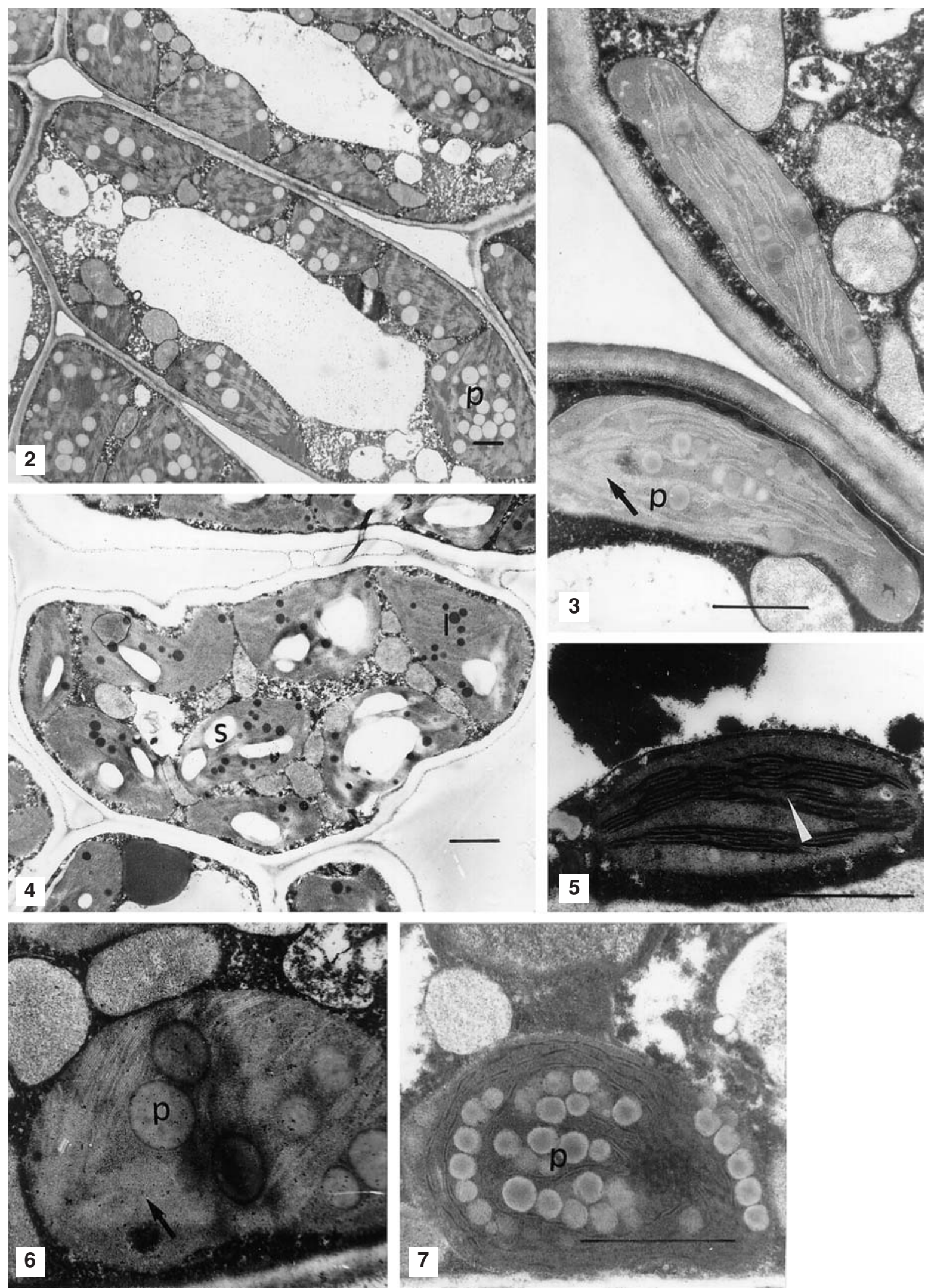

Fig. 2. Electron-light plastoglobuli $(p)$ in chloroplasts of palisade mesophyll of leaves without symptoms in late spring $(b a r=1 \mu \mathrm{m})$.

Fig. 3. Plastoglobuli (p) differring in electron density in chloroplasts of palisade mesophyll of leaves yellowed in autumn (disappearance of some part of thylakoids - arrow; bar $=1 \mu \mathrm{m}$ ).

Fig. 4. Spherical and rounded chloroplasts in mesophyll cells of leaves with interveinal chlorosis in late spring ( $\mathrm{s}-\mathrm{starch}, 1-$ lipids; bar $=1 \mu \mathrm{m})$.

Fig. 5. Type of chloroplast in cells of spongy mesophyll of leaves with interveinal chlorosis in late spring (disappearance of envelope, swelling of thylakoids - arrow, strongly electron-dark stroma between thylakoids; bar $=1 \mu \mathrm{m}$ ).

Fig. 6. Type of chloroplasts in cells of mesophylls of leaves yellowed in late spring (disappearance of envelope and thylakoids - arrow and occurrence of plastoglobuli (p) differing in electron densisty $(\mathrm{bar}=1 \mu \mathrm{m})$.

Fig. 7. Type of chloroplasts in cells of mesophylls (short sections of thylakoids with strongly osmiophilic inside, numerous plastoglobuli (p) varied in size (bar $=1 \mu \mathrm{m})$. 


\section{Leaves yellowed in autumn (control 2)}

The vacuolization increased visually in cells of both spongy and palisade mesophyll, as compared with the leaves without symptoms and collected in spring. Chloroplasts were generally elongated and lens-shaped, 2.5-4.5 $\mu \mathrm{m}$ in length. Many of them contained plastoglobuli (Fig. 3), which differred in electron density. In this aspect, the following types of plastoglobuli were observed: 1) more electron-light than stroma; 2) similarly electron-dark to stroma; 3) with central part more electron-dark than the border. Some chloroplasts lacked electron-light thylakoids. Starch grains were rare and observed only in some cells. Osmiophilic materials in the form of the granularity were observed in the cytoplasma of both kinds of mesophyll cells.

\section{Leaves with interveinal chlorosis in spring}

The cytoplasm of cells of both palisade and spongy mesophyll was rich in electron-dark granular deposit. The electron-dark material resembled that found in certain vacuoles. The majority of chloroplasts of both kinds of mesophyll cells were spherical shape or/and rounded (2.5-4.0 $\mu \mathrm{m}$ in length). Elongated and lens-shaped chloroplasts were rarely observed (Fig. 4). Thylacoids were not well-defined. In some cells, especially in spongy mesophyll, only electron-light residues of the thylakoids could be observed. These chloroplasts were filled with electron-dark (osmiophillic) globules. Single starch grains were also found in the majority of cells of both kinds mesophyll (Fig. 4). Occasionally, spongy mesophyll cells contained chloroplasts that were elongated or lens-shaped but much smaller (2$2.5 \mu \mathrm{m}$ in length) than those mentioned above. The smaller chloroplasts were lacking the envelope and some parts of their parallel membranes showed swelling (Fig. 5). The thylakoids were less crowded than in other chloroplasts. The stroma beween thylakoids was strongly electron-dark, similarly to the osmiophilic substances being in close contact with the chloroplasts (Fig. 5).

\section{Leaves yellowed in spring}

The cell cytoplasm of both palisade and spongy mesophyll was filled with electron-dark granules. The delimitation of certain organelles, like mitochondria and RE, appeared less clear than in the leaves without symptoms. Some cells contained a large and unshapely vacuole whereas in the others, several smaller vacuoles occurred. The majority of these vacuoles were filled with osmiophilic globules.

Two types of chloroplasts showing some abnormalities in comparison with the ones observed in the leaves of control 1 were found in both palisade and mesophyll cells. One type was characterized by spherical chloroplast (length: 1.5-2.5 $\mu \mathrm{m}$ ) whose envelopes were difficult to distinquish. The parallel thylakoids of these chloroplast were more electron-light than the stroma. The disappearance of some sections of thylakoid membranes was also noted. Plastoglobuli showed differences in electron density. Usually their border was darker than the internal part (Fig. 6). Another type of chloroplasts, showing spherical shape and length range of 2-2.5 $\mu \mathrm{m}$, was characterized by thylakoids looking as if they were divided into short sections. The inside of thylakoids was strongly osmiophilic. In chloroplasts of this type, platoglobuli were numerous and varied in size. The center of the plastoglobuli was more osmiophilic than their border (Fig. 7). In these chloroplasts, starch grains were scare and sometimes on many sections they could not be found.

\section{DISCUSSION}

Some of the senescence-related changes were observed in the chloroplasts of leaves of B. pendula showing premature yellowing and interveinal chlorosis. The changes include: reduced chloroplast size, degeneration of the membrane systems of thylakoids (swelling or disappearance) and increased electron density of plastoglobuli. Plastoglobuli differing in electron density occurred simultaneously in the chloroplast and the process of the density change started from their center or border. Generally, the features of senescence observed in chloroplasts in this study confirmed the results of Dodge (1970) and Pääkkönen et al. (1995), but in the present study, most of the strongly osmiophilic globules (lipids) and most starch grains were found in the chloroplasts of the spongy mesophyll in leaves showing interveinal chlorosis. The ultrastructural symptoms seem to be rather nonspecific. They were also detected in conifer needles with some stresses, such as ozone, sulphur dioxide and $\mathrm{K}$ and Mg deficiences (Fink 1989, 1991; Sutinen 1987).

The abnormal rounded and spherical shape of the chloroplasts with electron-dark inside of thylakoids and electrondark stroma between thylakoids were found only in the leaves exhibiting yellowing and chlorosis in spring. Moreover, in these leaves thylakoids were less crowded. Similar ultrastructural changes in chloroplasts of mesophyll cells of birch leaves were found after ozone treatment combined with drought (Pääkkönen et al. (1998), whereas protrusions of chloroplasts and disappearance of the envelope were observed after ozone exposure in spruce (Sutinen et al. 1992).

Generally, no major differences in ultrastructure of chloroplasts were found between spongy and palisade mesophyll cells. The changes in chloroplast ultrastructure in mesophyll cells of leaves showing premature yellowing and interveinal chlorosis resembled those observed during natural senescence. However, certain traits of chloroplast ultrastructure can suggest the influence of drought and ozone which injured these organelles. Ozone sensitivity of birch (Betula pendula) was indicated by some authors (Mattyssek et al. 1991; Pääkkönen et al. 1993). In nature plants are usually exposed to ozone and drought stress simultaneusly during warm periods of summer (McLaughlin and Downing 1996).

\section{ACKNOWLEDGEMENTS}

This work was a part of study supported by the Central Board of State Forests in Warsaw.

\section{LITERATURE CITED}

DODGE J.D. 1970. Changes in Chloroplasts Fine Structure During the Autumnal Senescence of Betula leaves. Ann. Bot. 34: 817-824.

FINK S. 1989. Pathological anatomy of conifer needles subjected to gaseous air pollutants or mineral deficiences. Aquilo Ser. Bot. 27: 1-6. 
FINK S. 1991. Structural changes in conifer needles due to $\mathrm{Mg}$ and K deficiency. Fert. Res. 27: 23-27.

GÜNTHARDT-GOERG M.S., MATYSSEK R., SCHEIDEGGER C., KELLER T. 1993. Differentiation and structural decline in leaves and bark of birch (Betula pendula) under low ozone concentrations. Trees 7: 104-114.

MATYSSEK R., GÜNTHARDT-GOERG M.S., KELLER T., SCHEIDEGGER C. 1991. Impairment of gas exchange and structure in birch leaves (Betula pendula) caused by low ozone concentrations. Trees 5: 5-13.

McLAUGHLIN D.J., DOWNING D.J. 1996. Interactive effects of ambient ozone and climate measured on growth of mature loblolly pine trees. Can J. For. Res. 26: 670-681.

PÄÄKKÖNEN E., PAASISALO S., HOLOPAINEN T., KÄRENLAMPI L. 1993. Growth and stomatal responses of birch (Betula pendula Roth.) clones to ozone in open-air and chamber fumigations. New Phytol. 125: 615-623.

PÄÄKKÖNEN E., HOLOPAINEN T., KÄRENLAMPI L. 1995. Ageing-related anatomical and ultrastructural changes in leaves of birch (Betula pendula Roth.) clones as affected by low ozone exposure. Ann. Bot. 75: 285-294.

PÄÄKKÖNEN E., HOLOPAINEN T., KÄRENLAMPI L. 1997. Differences in growth, leaf senescence and injury, and stomatal density in birch (Betula pendula Roth.) in relation to ambient levels of ozone in Finland. Environ. Poll. 96: 117-127.
PÄÄKKÖNEN E., VAHALA J., POHJOLAI M., HOLOPAINEN T., KÄRENLAMPI L. 1998. Physiological, stomatal and ultrastructural ozone responses in birch (Betula pendula Roth.) are modified by water stress. Plant, Cell and Environ. 21: 671-684.

PRZYBYŁ K., MIKOŁAJCZYK M., ŁABĘDZKI A. 1998. Wieloczynnikowa choroba brzozy w Polsce. Las Polski 19: 18-19. (in Polish)

PRZYBYŁ K., ŻŁOBIŃSKA-PODEJMA M. 2000. Effect of some Pseudomonas sp. and Erwinia herbicola on in vitro growth of Piptoporus betulinus. For. Path. 30: 321-328.

PRZYBYŁ K., MAŃKA M. 2000. Nutrient content in prematurely yellowed leaves and in brown discoloured trunk wood of Betula pendula trees. Phytopathol. Pol. 19: 97-106.

PRZYBYŁ K. 2001. Fungi and bacteria associated with the wet and brown wood in trunk of Betula pendula trees. Acta Soc. Bot. Pol. 70: 113-117.

REYNOLDS E.S. 1963. The use of lead citrate at high $\mathrm{pH}$ as an electron-opaque stain in electron microscopy. J. Cell. Biol. 17: 208-212.

SUTINEN S. 1987. Ultrastructure of mesophyll cells of spruce needles exposed to $\mathrm{O}_{3}$ alone and together with $\mathrm{SO}_{2}$. Eur. J. For. Pathol. 17: 362-368.

SUTINEN S., SKÄRBY L., WALLIN G., SELLDÉN G. 1992. Long-term exposure of Norway spruce, Picea abies (L.) Karst. to ozone in open-top chambers. New Phytol. 115: 345-355.

\section{ZMIANY W ULTRASTRUKTURZE CHLOROPLASTÓW MIĘKISZU LIŚCI BETULA PENDULA WYKAZUJĄCYCH CHLOROZĘ I PRZEDWCZESNE ŻÓŁKNIĘCIE}

\section{STRESZCZENIE}

Zmiany w ultrastrukturze chloroplastów miękiszu palisadowego i asymilacyjnego badano u liści Betula pendula wykazujących objawy chlorozy i przedwczesne żółknięcie. Liście do badań pobierano z górnej części korony (z przyrostów z czterech lat) w okresie od 26 maja do 7 czerwca. Kontrolę stanowiły liście nie wykazujące zmian chorobowych oraz liście pobierane w pierwszej połowie września.

Nie stwierdzono zasadniczych różnic w ultrastrukturze chloroplastów pomiędzy palisadowym i gąbczastym miękiszem. Niektóre zmiany w chloroplastach u liści wykazujących przedwczesne żółknięcie oraz chlorozę podobne były do zmian zachodzących w procesie naturalnego żółknięcia (wielkość chloroplastów, degeneracja tylakoidów gran i stromy oraz wzrastająca gęstość plastoglobuli). Najbardziej elektronowo ciemne ciała (lipidy) łącznie z ziarnami skrobi obserwowano w miękiszu gąbczastym liści wykazujących chlorozę. Sferyczne i okrągłe chloroplasty $\mathrm{z}$ elektronowo ciemnym wnętrzem tylakoidów oraz chloroplasty $\mathrm{z}$ elektronowo ciemną stromą stwierdzono u liści chlorotycznych i przedwcześnie żółtych. W dyskusji podkreślono czynniki, które mogły wpłynąć na obserwowane zmiany w chloroplastach.

SŁOWA KLUCZOWE: Betula pendula, liście, chloroza, przedwczesne żółknięcie, chloroplasty, mikroskop elektronowy-transmisyjny. 